\title{
Effects of different irrigation methods and plant densities on silage quality parameters of PR 31Y43 hybrid corn cultivar (Zea mays L. var. indentata [Sturtev.] L.H. Bailey)
}

\author{
Muhammet Karasahin ${ }^{1}$
}

\begin{abstract}
The yield and quality of corn silage is related to genotype as well as factors such as climate, soil conditions, altitude, planting time, plant density, irrigation, and harvesting time. This study was conducted to determine the effects of different irrigation methods (drip, subsoil drip, and subsoil capillary) and different plant densities (102 040, 119040 , and 142850 plant $\mathrm{ha}^{-1}$ ) on silage quality parameters of PR 31Y43 hybrid corn (Zea mays L. var. indentata [Sturtev.] L.H. Bailey) in 2011 and 2012 under ecological conditions in Eskipazar-Karabuk, Turkey. Plant densities were significantly different on fresh ear ratio and plant crude protein (CP) yield in both years under study. The highest fresh ear ratio values were obtained with 102040 and 119040 plant ha $^{-1}$ densities and the highest plant CP yield with 142850 plant ha $^{-1}$. While the irrigation method $\times$ plant density interactions were significant for silage CP ratio in the first year, they were significant on fresh ear ratio in the second year. The highest fresh ear ratio values were obtained from subsoil capillary $\times 119040$ plant ha $^{-1}$ and drip $\times 119040$ plant ha $^{-1}$ interactions; the highest plant and silage CP ratio values were obtained from subsoil capillary $\times 142850$ plant ha $^{-1}$ and subsoil drip $\times 102040$ plant ha $^{-1}$ interactions. As a result of the research, high Flieg scores were obtained from each irrigation method and plant density. When plant CP yield is taken into consideration, the 142850 plant $\mathrm{ha}^{-1}$ density is more important.
\end{abstract}

Key words: Corn, drip irrigation, subsoil drip irrigation, subsoil capillary irrigation, plant density, silage quality parameters.

\section{INTRODUCTION}

Even if hunger is not currently an issue in Turkey, we can still observe unbalanced nutrition dependent on cereals. Consumption of animal proteins should be increased to at least 50\% for balanced nutrition (Tukel and Hatipoglu, 1997). The increase in the consumption of animal products can only be possible by producing these products in our own country in adequate amounts and at reasonable costs. Feed costs include $65 \%$ of animal production costs. Corn (Zea mays L.) is the most important silage plant which can satisfy the demand for both concentrate feed and fodder. The concentrate feed requirement decreases by $33-50 \%$ in animals fed with corn silage (Sade and Soylu, 2008). Corn is the most important plant that is grown for silage both in our country and worldwide (Turgut, 2002).

The yield and the quality of corn silage is related to genotype as well as factors such as climate, soil conditions, altitude, planting time, plant density,

${ }^{1}$ Karabuk University Eskipazar Vocational School, Department of Plant and Animal Production, Karabuk, Turkey.

(mkarasahin@karabuk.edu.tr).

Received: 11 April 2013.

Accepted: 23 December 2013.

doi:10.4067/S0718-58392014000100016 irrigation, and harvesting time (Cusicanqui and Lauer, 1999). A suitable plant density must be provided to obtain a high yield in corn production. The determination of optimum plant density is a way to enable the plant to benefit from available water and nutrients in the soil; light energy is also highly important to decrease production costs (Kirtok, 1998). The corn ear, leaf, and stem ratios affect silage quality (Saruhan and Sireli, 2005). Alcicek and Ozkan (1997) stated that the most important principle to determine silo feed quality was the Flieg score obtained as a result of chemical evaluation, which is done according to the appearance recognized by sense organs and silo acids; they also said that DM and $\mathrm{pH}$ content of silo feed were also important. Ideally corn silage must contain $28 \%$ to $42 \% \mathrm{DM}$ and $40 \%$ to $50 \%$ grain at moment it is ensiled. When corn is harvested at the dough stage and these conditions are provided, it will have a suitable DM content as well as sufficient DM soluble in water and a lower buffer capacity (Ergun et al., 2004).

Nowadays, using irrigation methods and systems that will not cause drainage and salinity problems in soil, which use less irrigation water with more economical applications, have become more and more important (Aras, 2006). Arranging precise irrigation programs and using more effective irrigation methods are the best ways 
to increase yield and decrease the amount of irrigation water used in agriculture. These problems have partly been solved with the subsoil drip irrigation method. However, in this method the emitters are plugged by the plant roots and the use of chemical weed controllers thus becomes necessary to prevent this problem. As a result, plant roots are damaged. The subsoil capillary irrigation system was developed to prevent all these negative effects. This new irrigation system was used as a third irrigation method in our research.

The aim of this study was to determine the effects of different irrigation methods and plant densities on silage quality parameters of PR 31 Y43 hybrid corn (Zea mays L. var. indentata [Sturtev.] L.H. Bailey).

\section{MATERIALS AND METHODS}

The study was conducted in the experimental fields of Eskipazar Vocational High School in 2011 and 2012 under ecological conditions of the district of Eskipazar (405' $17^{\prime}$ " N, 32 30'45" E; $781 \mathrm{~m}$ a.s.1.) in the province of Karabuk, Turkey. The hybrid corn cv. PR 31Y43 was used as material in this study. Three different irrigation methods (drip, subsoil drip, and subsoil capillary) and three different plant densities $(70 \times 14 \mathrm{~cm}$ : 102040 plant ha $^{-1} ; 70 \times 12 \mathrm{~cm}: 119040$ plant ha ${ }^{-1}$; and $70 \times 10 \mathrm{~cm}$ : 142850 plant ha $^{-1}$ ) were investigated. Composite fertilizer 13.24.12.10.1.1 (13\% N, 24\% $\mathrm{P}_{2} \mathrm{O}_{5}, 12 \% \mathrm{~K}_{2} \mathrm{O}, 10 \% \mathrm{SO}_{3}$, $1 \% \mathrm{Zn}, 1 \% \mathrm{Fe}$ ) was applied as the base-fertilizer and ammonium nitrate $(33 \% \mathrm{~N})$ was used as top-dressing fertilizer. Drip lines (Hydro PCND, John Deere Water, San Marcos, California, USA) with $50 \mathrm{~cm}$ emitter spacing, 16 mm diameter, and $2.35 \mathrm{~L} \mathrm{~h}^{-1}$ flow rate for each emitter were used in the drip, subsoil drip, and subsoil capillary irrigation methods. Irrigation was done by coating these drip lines with microfiber material in plots where the subsoil capillary irrigation method would be used.

The experimental design was a randomized complete block in a split-plot arrangement with three replicates. The irrigation methods (drip, subsoil drip, and subsoil capillary) for use in the main plots and plant densities (102 040, 119 040, and 142850 plant ha $^{-1}$ ) for use in the split-plots were selected randomly. The split-plot size was $2.8 \times 5 \mathrm{~m}$ with four rows per plot.

Manual planting was done on 25 May in the first year and on 10 May in the second year. Two seeds were sown for each plant density and manually thinned after emergence. After plants emerged and rows were cleared, the first hoeing was done when the plant was at the 4-5 leaf stage; three different irrigation methods were applied to the plots. The drip lines were placed $1.4 \mathrm{~m}$ apart and each drip line was centered between two corn rows spaced $70 \mathrm{~cm}$ for the three irrigation methods. Drip lines were buried with an installation depth of $20 \mathrm{~cm}$ in the subsoil drip irrigation method. The drip lines were coated with dispersion material made of polypropylene microfibers with a higher water-holding and transition capacity and outer surface covered with polyethylene film; this new irrigation system was the subsoil capillary irrigation method. These capillary drip lines were buried just as in the subsoil drip irrigation method. Potable water was used in the study and was classified as low $\mathrm{Na}$ and medium salinity according to the analysis.

A transition climate between the Black Sea and continental climate occurs in the Eskipazar district where the experiment was carried out. Some of the climate data recorded in the Eskipazar district during the 20112012 corn growing periods and the long term means of these data (1985-2006) are given in Table 1. Total rain, temperature and relative humidity means in 2011 and 2012 were similar to the long term means (Table 1).

Soil samples were taken from 0-30 cm depths and analyzed to determine physical and chemical properties. Analysis results of soil samples are given in Table 2; soils are clay-loam textured with low organic matter content $(1.49 \%)$.

A time-domain reflectometer (TDR 300, Spectrum Technologies, Plainfield, Illinois, USA) was used to measure soil moisture and determine the irrigation program during the study. This method is based on measuring travelling time between two parallel points in the soil of the electromagnetic waves sent from a voltage source through metal bars buried in the soil. For the calibration of the TDR 300 device, a plastic case with dimensions of $40 \times 70 \times 25 \mathrm{~cm}$ was filled with soil taken from the experimental field and then completely saturated with water. Afterwards, undisturbed soil samples were taken periodically and gravimetric moisture estimates were made with an incubator; these estimates were transformed into volumetric values and the related TDR readings were recorded. The TDR calibration curve was constructed with the data.

Table 1. Climatic data of the research location in 2011 and 2012 and the long term mean (1985-2006) in Eskipazar, Turkey.

\begin{tabular}{|c|c|c|c|c|c|c|c|c|c|}
\hline \multirow[b]{2}{*}{ Months } & \multicolumn{3}{|c|}{ Precipitation } & \multicolumn{3}{|c|}{$\begin{array}{c}\text { Mean } \\
\text { temperature }\end{array}$} & \multicolumn{3}{|c|}{$\begin{array}{l}\text { Relative } \\
\text { humidity }\end{array}$} \\
\hline & 2011 & 2012 & $\begin{array}{l}\text { Long } \\
\text { term }\end{array}$ & 2011 & 2012 & $\begin{array}{l}\text { Long } \\
\text { term }\end{array}$ & 2011 & 2012 & $\begin{array}{l}\text { Long } \\
\text { term }\end{array}$ \\
\hline & & $\mathrm{mr}$ & & & ${ }^{\circ} \mathrm{C}$ & & & $\%$ & \\
\hline May & 68.4 & 68.2 & 57.1 & 13.4 & 15.4 & 14.3 & 73.9 & 66.7 & 60.2 \\
\hline June & 54.8 & 21.8 & 54.8 & 16.9 & 20.2 & 17.9 & 72.3 & 58.7 & 60.8 \\
\hline July & 8.2 & 51.4 & 24.8 & 21.6 & 22.6 & 20.9 & 63.1 & 57.7 & 55.4 \\
\hline August & 17.0 & 48.0 & 22.9 & 19.9 & 19.9 & 21.1 & 62.0 & 59.9 & 53.9 \\
\hline September & 4.4 & 6.0 & 21.6 & 17.1 & 18.7 & 16.3 & 57.4 & 54.7 & 57.5 \\
\hline Total/Mean & 152.8 & 195.4 & 181.2 & 17.8 & 19.4 & 18.1 & 65.7 & 59.5 & 57.6 \\
\hline
\end{tabular}

Table 2. Physical and chemical soil properties of the research location in Eskipazar, Turkey.

\begin{tabular}{|c|c|c|c|}
\hline \multicolumn{2}{|l|}{ Properties } & \multicolumn{2}{|l|}{ Properties } \\
\hline Sand, $\%$ & 38.0 & $\mathrm{pH}$ & 7.60 \\
\hline Silt, \% & 20.0 & Salt, $\%$ & 0.04 \\
\hline Clay, \% & 42.0 & Lime, $\%$ & 37.59 \\
\hline Texture class & Clay-Loam & Field capacity, $\%,\left(\mathrm{v} \mathrm{v}^{-1}\right)$ & 26.32 \\
\hline Total $\mathrm{N}, \mathrm{kg} \mathrm{ha}^{-1}$ & 0.34 & Wilting point, $\%,\left(\mathrm{v} \mathrm{v}^{-1}\right)$ & 16.25 \\
\hline $\mathrm{P}_{2} \mathrm{O}_{5}, \mathrm{~kg} \mathrm{ha}^{-1}$ & 23.60 & Bulk density, $\mathrm{g} \mathrm{cm}^{-3}$ & 1.23 \\
\hline $\mathrm{K}_{2} \mathrm{O}, \mathrm{kg} \mathrm{ha}^{-1}$ & 170.10 & Organic matter, $\%$ & 1.49 \\
\hline
\end{tabular}


The TDR value 55 was read against field capacity $(26.32 \% \mathrm{v} / \mathrm{v}), 42$ against $30 \%$ consumption of readily available soil water $(23.29 \% \mathrm{v} / \mathrm{v})$, and 25 against permanent wilting point $(16.25 \% \mathrm{v} / \mathrm{v})$. The TDR readings were taken for soil depths of 20 and $40 \mathrm{~cm}$. In all three irrigation systems, the accuracy of the amount of irrigation water was controlled with the TDR readings taken $24 \mathrm{~h}$ after irrigation. The amounts of irrigation water measured with water counters were recorded and the total amounts used at the end of the season were defined.

When plants grew to a height of approximately 40 $\mathrm{cm}$, secondary hoeing was done. In all plant densities, fertilization took place by calculating the rate as follows: $3 \mathrm{~g} \mathrm{~N}_{\text {plant }}{ }^{-1}, 1.4 \mathrm{~g} \mathrm{P}_{2} \mathrm{O}_{5}$ plant $^{-1}$, and $0.7 \mathrm{~g} \mathrm{~K}_{2} \mathrm{O}$ plant ${ }^{-1}$. A part of $\mathrm{N}$, whole $\mathrm{P}$, and $\mathrm{K}$ were given with the base fertilizer $\left(0.75 \mathrm{~g} \mathrm{~N}\right.$ plant $^{-1}, 1.4 \mathrm{~g} \mathrm{P}_{2} \mathrm{O}_{5}$ plant $^{-1}, 0.7 \mathrm{~g} \mathrm{~K}_{2} \mathrm{O}$ plant $\left.{ }^{-1}\right)$. The rest of $\mathrm{N}\left(2.25 \mathrm{~g} \mathrm{plant}^{-1}\right)$ was provided with each irrigation event in the form of ammonium nitrate $(33 \% \mathrm{~N})$.

After removing border effects, two center rows of each split plot were harvested. Harvesting at the milkline stage was between $50 \%$ and $75 \%$. The basic plant measurements were taken on five plants randomly selected from two center rows of each split-plot. Then the plants were transformed into silage with machines and packaged. The packaging materials were $57 \times 75$ sized, $80 \mu$ thick white bags produced from $20 \%$ virgin and $80 \%$ recycled low density polyethylene. The silage-based analyses were made after a fermentation period of $75 \mathrm{~d}$. Silage quality category can be determined through a regression equation using the relationship between the $\mathrm{pH}$ value and DM content of silage (Geren, 2001).

Flieg score: $[220+2 \times($ silage DM (\%) - 15) $]-(40 \times$ silage $\mathrm{pH}$ value)

The Flieg score obtained from the above equation gives important clues about the quality of silage according to the criteria given in Table 3. The DM (\%), pH, silage quality category, fresh ear ratio (\%), dry leaf, ear, and stem ratios (\%), dry leaf-stem ratio (\%), plant $\mathrm{CP}(\%)$, plant $\mathrm{CP}$ yield $\left(\mathrm{t} \mathrm{ha}^{-1}\right)$, and silage $\mathrm{CP}(\%)$ were examined in these analyses (TIVT, 2010).

All data were analyzed using ANOVA according to a randomized complete block in a split-plot experimental design. The LSD procedure was used to separate mean values when the F-test was significant (Mstat-C, 1980).

\section{RESULTS AND DISCUSSION}

Silage dry matter, pH, Flieg score, and quality category In the first year, silage $\mathrm{pH}$ values obtained from plant densities were significantly different $(\mathrm{P}<0.05)$. Highest silage $\mathrm{pH}$ value (4.02) was obtained with 102040 plant $\mathrm{ha}^{-1}$ and took place in the first group (a) and the lowest silage $\mathrm{pH}$ value (3.93) was obtained with 142850 plant $\mathrm{ha}^{-1}$ and took place in the last (b) group (Table 4). In both years, no significant difference was found between silage DM level, Flieg score, and silage quality category values (Table 4).

Fresh ear ratio, and dry leaf, dry ear, and dry stem ratios

In both years, fresh ear ratio values obtained from plant densities were significantly different $(\mathrm{P}<0.05$ and $\mathrm{P}<$ 0.01 , respectively). In the first year, the highest fresh ear

Table 3. Flieg scores and silage quality categories that are calculated with $\mathrm{DM}$ and $\mathrm{pH}$ values.

\begin{tabular}{lc}
\hline Flieg scores & Silage quality categories \\
\hline $0-20$ & Poor \\
$21-40$ & Low \\
$41-60$ & Medium \\
$61-80$ & Good \\
$81-100$ & Well \\
\hline
\end{tabular}

Table 4. Effects of irrigation and plant density on silage DM, silage pH, Flieg score, and silage quality category.

\begin{tabular}{|c|c|c|c|c|c|c|c|c|c|}
\hline \multirow[b]{2}{*}{ Irrigation (I) } & \multirow{2}{*}{$\begin{array}{l}\text { Plant density (D) } \\
\text { plant ha-1 }\end{array}$} & \multicolumn{2}{|c|}{$\begin{array}{c}\text { Silage DM } \\
\%\end{array}$} & \multicolumn{2}{|c|}{$\begin{array}{l}\text { Silage } \\
\mathrm{pH}\end{array}$} & \multicolumn{2}{|c|}{$\begin{array}{l}\text { Flieg } \\
\text { score }\end{array}$} & \multicolumn{2}{|c|}{$\begin{array}{c}\text { Silage quality } \\
\text { category }\end{array}$} \\
\hline & & 2011 & 2012 & 2011 & 2012 & 2011 & 2012 & 2011 & 2012 \\
\hline \multirow[t]{3}{*}{ Drip } & 102040 & 29.9 & 33.7 & 4.02 & 4.09 & 88.9 & 93.9 & Well & Well \\
\hline & 119040 & 29.2 & 33.4 & 3.97 & 4.01 & 89.8 & 96.3 & Well & Well \\
\hline & 142850 & 28.4 & 29.3 & 3.89 & 4.05 & 91.3 & 86.8 & Well & Well \\
\hline \multirow[t]{3}{*}{ Subsoil drip } & 102040 & 29.3 & 30.7 & 4.01 & 4.03 & 88.3 & 90.2 & Well & Well \\
\hline & 119040 & 29.0 & 30.4 & 3.99 & 3.94 & 88.3 & 93.3 & Well & Well \\
\hline & 142850 & 30.6 & 31.7 & 4.04 & 3.97 & 89.5 & 94.4 & Well & Well \\
\hline \multirow[t]{3}{*}{ Subsoil capillary } & 102040 & 31.1 & 33.1 & 4.02 & 3.97 & 91.3 & 97.7 & Well & Well \\
\hline & 119040 & 27.2 & 32.5 & 3.99 & 4.05 & 85.0 & 92.8 & Well & Well \\
\hline & 142850 & 30.5 & 30.2 & 3.86 & 4.05 & 96.3 & 88.6 & Well & Well \\
\hline I & Drip & 29.2 & 32.1 & 3.96 & 4.05 & 90.0 & 92.3 & Well & Well \\
\hline \multirow[t]{2}{*}{ Mean } & Subsoil drip & 29.6 & 30.9 & 4.01 & 3.98 & 88.8 & 92.6 & Well & Well \\
\hline & Subsoil capillary & 29.6 & 31.9 & 3.96 & 4.02 & 90.9 & 93.0 & Well & Well \\
\hline LSD & & ns & ns & ns & ns & ns & ns & & \\
\hline $\mathrm{D}$ & 102040 & 30.1 & 32.5 & $4.02 \mathrm{a}$ & 4.03 & 89.6 & 93.9 & Well & Well \\
\hline \multirow{2}{*}{ Mean } & 119040 & 28.5 & 32.1 & $3.98 \mathrm{ab}$ & 4.00 & 87.7 & 94.1 & Well & Well \\
\hline & 142850 & 29.8 & 30.4 & $3.93 b$ & 4.02 & 92.4 & 89.9 & Well & Well \\
\hline $\mathrm{LSD}$ & & ns & ns & $0.05^{*}$ & ns & ns & $\mathrm{ns}$ & & \\
\hline $\mathrm{I} \times \mathrm{D}$ interaction & LSD & ns & ns & ns & ns & ns & ns & & \\
\hline
\end{tabular}

ns: non significant, LSD: least significant difference. 
ratio (42.5) was obtained with 102040 plant ha $^{-1}$ and took place in the first group (a). In the second year, the highest fresh ear ratio values (40.4 and 40.3, respectively) were obtained with 102040 and 119040 plant ha $^{-1}$ and took place in the first group (a) (Table 5).

In the second year, fresh ear ratio values obtained from the irrigation method $\times$ plant density interactions were significant $(\mathrm{P}<0.01)$. The highest fresh ear ratio values (41.7 and 41.6, respectively) were obtained from the subsoil capillary $\times 119040$ plant ha ${ }^{-1}$ and drip $\times 119040$ plant ha $^{-1}$ interactions that took place in the first group (a) (Table 5). In both years no significant difference was found between dry leaf, ear, and stem ratio values (Table 5).

Dry leaf-stem ratio, plant and silage crude protein, and plant crude protein yield

In the first year, plant $\mathrm{CP}$ values obtained from irrigation method $\times$ plant density interactions were significant $(\mathrm{P}<$ 0.01). The highest plant $\mathrm{CP}$ values were obtained from subsoil capillary $\times 142850$ plant ha ${ }^{-1}$ and subsoil drip $\times$ 102040 plant ha $^{-1}$ interactions that took place in the first group (a) (Table 6). In the second year, plant $\mathrm{CP}$ values obtained from irrigation methods were significant $(\mathrm{P}$ $<0.05)$. The highest plant CP (8.7) was obtained from subsoil capillary irrigation and took place in the first group (a) (Table 6). In both years, plant CP yield values obtained from plant densities were significant $(\mathrm{P}<0.05)$. The highest plant CP yields (1.89 and 1.82, respectively) were obtained with 142850 plant ha $^{-1}$ and took place in the first group (a) (Table 6).

In the first year, silage $\mathrm{CP}$ values obtained from irrigation methods were significantly different $(\mathrm{P}<0.01)$. The highest silage CP (7.3) was obtained from subsoil drip irrigation and took place in the first group (a) (Table
6). In the first year, silage $\mathrm{CP}$ values obtained from plant densities were significantly different $(\mathrm{P}<0.01)$. The highest silage CP (7.2) was obtained with 119040 plant $\mathrm{ha}^{-1}$ and took place in the first group (a) (Table 6). In the first year, silage $\mathrm{CP}$ values obtained from irrigation method $\times$ plant density interactions were significant $(P$ $<0.01)$. The highest silage $\mathrm{CP}$ value was obtained from subsoil drip $\times 102040$ plant ha $^{-1}$ interactions and took place in the first group (a) (Table 6). In both years no significant difference was found between dry leaf-stem ratio values (Table 6).

In both years under study plant densities were significant on fresh ear ratios and plant CP yield. The highest fresh ear ratio values were obtained with 102040 and 119040 plant ha $^{-1}$ densities and the highest plant CP yield was obtained with 142850 plant ha ${ }^{-1}$ density. In the first year, plant densities were significant on silage $\mathrm{pH}$ and silage CP (Tables 4, 5, and 6). In this study, plants did not encounter water stress in the growing seasons due to optimum irrigation management, which created the appropriate conditions to grow more plants per unit area (Karasahin, 2013).

Results obtained from many research studies on the effects of different irrigation methods and plant densities on silage quality parameters of corn support our findings (Cox and Cherney, 2001; Iptas and Acar, 2006; Yilmaz et al., 2007; Budakli Carpicı et al., 2010), while some studies provide different results (Cusicanqui and Lauer, 1999; Stanton et al., 2007; Ozturk et al., 2008; Baghdadi et al., 2012). The similarities and differences in results regarding plant densities may be due to the ecological conditions and differences and similarities of the genetics of the cultivars used in these studies.

Irrigation methods were significant for silage $\mathrm{CP}$ in the first year and the highest value was obtained from

Table 5. Effects of irrigation and plant density on fresh ear, dry leaf, dry ear, and dry stem ratios.

\begin{tabular}{|c|c|c|c|c|c|c|c|c|c|}
\hline \multirow[b]{2}{*}{ Irrigation (I) } & \multirow{2}{*}{$\begin{array}{l}\text { Plant density } \\
\text { (D) }\end{array}$} & \multicolumn{2}{|c|}{ Fresh ear ratio } & \multicolumn{2}{|c|}{ Dry leaf ratio } & \multicolumn{2}{|c|}{ Dry ear ratio } & \multicolumn{2}{|c|}{ Dry stem ratio } \\
\hline & & 2011 & 2012 & 2011 & 2012 & 2011 & 2012 & 2011 & 2012 \\
\hline & plant ha ${ }^{-1}$ & & & & 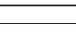 & & & & $\bar{z}$ \\
\hline \multirow[t]{3}{*}{ Drip } & 102040 & 42.8 & 39.1abcd & 16.3 & 16.8 & 53.5 & 50.5 & 30.3 & 32.6 \\
\hline & 119040 & 40.9 & $41.6 \mathrm{a}$ & 15.4 & 16.3 & 51.0 & 55.6 & 33.6 & 28.1 \\
\hline & 142850 & 39.1 & 38.9abcd & 14.0 & 18.8 & 45.4 & 48.1 & 40.6 & 33.0 \\
\hline \multirow[t]{3}{*}{ Subsoil drip } & 102040 & 42.6 & $41.5 \mathrm{ab}$ & 15.2 & 16.5 & 52.2 & 48.3 & 32.6 & 35.2 \\
\hline & 119040 & 40.5 & $37.6 \mathrm{~cd}$ & 15.6 & 19.9 & 54.5 & 43.8 & 29.9 & 36.3 \\
\hline & 142850 & 40.5 & $38.0 \mathrm{bcd}$ & 17.7 & 17.3 & 48.8 & 48.8 & 33.5 & 33.9 \\
\hline \multirow[t]{3}{*}{ Subsoil capillary } & 102040 & 42.2 & $40.5 \mathrm{abc}$ & 15.8 & 17.0 & 53.1 & 50.4 & 31.1 & 32.5 \\
\hline & 119040 & 43.4 & $41.7 \mathrm{a}$ & 15.6 & 17.5 & 52.8 & 48.0 & 31.6 & 34.5 \\
\hline & 142850 & 40.2 & $36.1 \mathrm{~d}$ & 17.3 & 18.4 & 50.9 & 50.2 & 31.7 & 31.4 \\
\hline $\mathrm{I}$ & Drip & 40.9 & 39.9 & 15.2 & 17.3 & 50.0 & 51.4 & 34.8 & 31.2 \\
\hline \multirow[t]{2}{*}{ Mean } & Subsoil drip & 41.2 & 39.0 & 16.2 & 17.9 & 51.8 & 47.0 & 32.0 & 35.1 \\
\hline & Subsoil capillary & 41.9 & 39.4 & 16.2 & 17.6 & 52.3 & 49.5 & 31.5 & 32.8 \\
\hline LSD & & ns & ns & ns & ns & ns & ns & ns & ns \\
\hline $\mathrm{D}$ & 102040 & $42.5 \mathrm{a}$ & $40.4 \mathrm{a}$ & 15.8 & 16.8 & 52.9 & 49.7 & 31.3 & 33.4 \\
\hline \multirow[t]{2}{*}{ Mean } & 119040 & 41.6ab & $40.3 \mathrm{a}$ & 15.5 & 17.9 & 52.8 & 49.1 & 31.7 & 32.0 \\
\hline & 142850 & $39.9 \mathrm{~b}$ & $37.7 \mathrm{~b}$ & 16.3 & 18.2 & 48.4 & 49.0 & 35.3 & 32.8 \\
\hline LSD & & $1.75^{*}$ & $2.05^{* * *}$ & ns & ns & ns & ns & ns & ns \\
\hline $\mathrm{I} \times \mathrm{D}$ interaction & LSD & ns & $3.55^{* *}$ & ns & ns & ns & ns & ns & ns \\
\hline
\end{tabular}

* ${ }^{* *}$ Significant at 0.05 and 0.01 probability level, ns: non significant, LSD: least significant difference. 
Table 6. Effects of irrigation and plant density on dry leaf-stem ratio, plant and silage crude protein, and plant crude protein yield.

\begin{tabular}{|c|c|c|c|c|c|c|c|c|c|}
\hline \multirow[b]{2}{*}{ Irrigation (I) } & \multirow[b]{2}{*}{ Plant density (D) } & \multicolumn{2}{|c|}{$\begin{array}{l}\text { Dry leaf-stem } \\
\text { ratio }\end{array}$} & \multicolumn{2}{|c|}{$\begin{array}{l}\text { Plant crude } \\
\text { protein }\end{array}$} & \multicolumn{2}{|c|}{$\begin{array}{l}\text { Plant crude } \\
\text { protein yield }\end{array}$} & \multicolumn{2}{|c|}{$\begin{array}{l}\text { Silage crude } \\
\text { protein }\end{array}$} \\
\hline & & 2011 & 2012 & 2011 & 2012 & 2011 & 2012 & 2011 & 2012 \\
\hline & plant ha-1 & 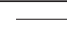 & 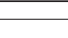 & 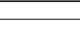 & $\bar{z}$ & - & $1-$ & $\longrightarrow$ & 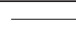 \\
\hline \multirow[t]{3}{*}{ Drip } & 102040 & 54.2 & 51.8 & $7.4 \mathrm{~b}$ & 7.5 & 1.32 & 1.61 & $7.1 \mathrm{ab}$ & 6.9 \\
\hline & 119040 & 49.1 & 58.6 & $7.3 \mathrm{~b}$ & 7.4 & 1.86 & 1.63 & $7.2 \mathrm{ab}$ & 7.1 \\
\hline & 142850 & 43.3 & 57.3 & $7.3 \mathrm{~b}$ & 7.9 & 1.84 & 1.61 & $6.5 \mathrm{~cd}$ & 7.3 \\
\hline \multirow[t]{3}{*}{ Subsoil drip } & 102040 & 47.1 & 47.4 & $8.0 \mathrm{a}$ & 7.2 & 1.71 & 1.41 & $7.7 \mathrm{a}$ & 6.5 \\
\hline & 119040 & 52.9 & 55.3 & $7.5 b$ & 7.7 & 1.62 & 1.40 & $7.3 \mathrm{ab}$ & 6.0 \\
\hline & 142850 & 53.0 & 51.4 & $7.4 \mathrm{~b}$ & 8.4 & 1.71 & 1.96 & $7.0 \mathrm{bc}$ & 7.2 \\
\hline \multirow[t]{3}{*}{ Subsoil capillary } & 102040 & 51.0 & 52.5 & $7.2 \mathrm{~b}$ & 8.5 & 1.56 & 1.69 & $6.2 \mathrm{~d}$ & 7.1 \\
\hline & 119040 & 49.5 & 51.7 & $7.3 b$ & 9.4 & 1.74 & 1.73 & $7.1 \mathrm{ab}$ & 7.9 \\
\hline & 142850 & 54.8 & 58.7 & $8.0 \mathrm{a}$ & 8.1 & 2.11 & 1.88 & $6.9 \mathrm{bc}$ & 7.6 \\
\hline I & Drip & 48.9 & 55.9 & 7.3 & $7.6 \mathrm{~b}$ & 1.67 & 1.62 & $6.9 \mathrm{~b}$ & 7.1 \\
\hline \multirow[t]{2}{*}{ Mean } & Subsoil drip & 51.0 & 51.4 & 7.6 & $7.8 \mathrm{~b}$ & 1.68 & 1.59 & $7.3 \mathrm{a}$ & 6.6 \\
\hline & Subsoil capillary & 51.8 & 54.3 & 7.5 & $8.7 \mathrm{a}$ & 1.80 & 1.77 & $6.7 b$ & 7.5 \\
\hline LSD & & ns & $\mathrm{ns}$ & ns & $0.61^{*}$ & ns & $\mathrm{ns}$ & $0.34^{* *}$ & $\mathrm{~ns}$ \\
\hline $\mathrm{D}$ & 102040 & 50.8 & 50.6 & 7.5 & 7.7 & $1.53 \mathrm{~b}$ & $1.57 \mathrm{~b}$ & $7.0 \mathrm{ab}$ & 6.8 \\
\hline \multirow[t]{2}{*}{ Mean } & 119040 & 50.5 & 55.2 & 7.4 & 8.2 & $1.74 \mathrm{ab}$ & $1.59 \mathrm{~b}$ & $7.2 \mathrm{a}$ & 7.0 \\
\hline & 142850 & 50.4 & 55.8 & 7.6 & 8.1 & $1.89 \mathrm{a}$ & $1.82 \mathrm{a}$ & $6.8 \mathrm{~b}$ & 7.4 \\
\hline LSD & & ns & $\mathrm{ns}$ & ns & ns & $0.21^{*}$ & $0.18^{*}$ & $0.34^{* *}$ & $\mathrm{~ns}$ \\
\hline $\mathrm{I} \times \mathrm{D}$ interaction & LSD & ns & ns & $0.48^{* *}$ & ns & ns & ns & $0.59^{* *}$ & $\mathrm{~ns}$ \\
\hline
\end{tabular}

${ }^{*},{ }^{* *}$ Significant at 0.05 and 0.01 probability level, ns: non significant, LSD: least significant difference.

subsoil drip irrigation. Irrigation methods have also been statistically significant for plant $\mathrm{CP}$ in the second year and the highest values were obtained from subsoil capillary irrigation.

Irrigation method $\times$ plant density interactions were significant for plant and silage CP in the first year and significant on fresh ear ratios in the second year. The highest fresh ear ratio values were obtained from subsoil capillary $\times 119040$ plant ha $^{-1}$ and drip $\times 119040$ plant ha $^{-1}$ interactions and the highest plant and silage $\mathrm{CP}$ values were obtained from subsoil capillary $\times 142850$ plant ha $^{-1}$ and subsoil drip $\times 102040$ plant ha $^{-1}$ interactions (Tables 5 and 6).

The findings of our research provided similar results with most of the previous research studies done to determine the effect of different irrigation methods on silage quality parameters of corn cultivars (Camp et al., 1989; Howell et al., 1997; Montemayor et al., 2006; Hassanli et al., 2009; Karasahin and Sade, 2011); however, they also provided different results with others (Schneider et al., 2001; Humphreys et al., 2005; Kheira, 2009). The differences and similarities between results of these research studies regarding the effect of irrigation methods on corn yield and silage quality parameters may be due to the differences and similarities of the ecological conditions of the locations where the studies were carried out as well as the cultural conditions such as fertilization, soil texture, and genetics of the cultivars.

\section{CONCLUSIONS}

As a result of the research study, high Flieg scores are obtained with each irrigation method and plant density. When plant CP yield is taken into consideration, the 142 850 plant ha $^{-1}$ density becomes more important.

\section{LITERATURE CITED}

Alcicek, A., and K. Ozkan. 1997. Silo yemlerinde fiziksel ve kimyasal yöntemlerle silaj kalitesinin saptanması. p. 241-247. Türkiye Birinci Silaj Kongresi, Bursa, Turkey.

Aras, I. 2006. Drip irrigation. Journal of Field Crops Central Research Institute 15:49-60.

Baghdadi, A., A.R. Halim, M. Majidian, W.N.W. Daud, and I. Ahmad. 2012. Plant density and tillage effects on forage corn quality. Journal of Food, Agriculture and Environment 10:366370.

Budakli Carpici, E., N. Celik, and G. Bayram. 2010. Yield and quality of forage maize as influenced by plant density and nitrogen rate. Turkish Journal of Field Crops 15:128-132.

Camp, C.R., E.J. Sadler, and W.J. Busscher. 1989. Subsurface and alternate-middle micro irrigation for the Southeastern Coastal Plain. Transactions of ASAE 32:451-456.

Cox, W.J., and D.J.R. Cherney. 2001. Row spacing, plant density and nitrogen effects on corn silage. Agronomy Journal 93:597602.

Cusicanqui, J.A., and J.G. Lauer. 1999. Plant density and hybrids influence on corn forage yield and quality. Agronomy Journal 91:911-915.

Ergun, A., S.D. Tuncer, I. Colpan, G. Yıldız, M.K. Kucukersan, S. Kucukersan, et al. 2004. Yemler, yem hijyeni ve teknolojisi. Pozitif Matbacılık, Ankara, Turkey.

Geren, H. 2001. Effect of sowing dates on silage characteristics of different maize cultivars grown as second crop under Bornova conditions. The Journal of Ege University Faculty of Agriculture 38:47-54.

Hassanli, A.M., M.A. Ebrahimizadeh, and S. Beecham. 2009. The effects of irrigation methods with effluent and irrigation scheduling on water use efficiency and corn yields in an arid region. Agricultural Water Management 96:93-99.

Howell, A.T., D.A. Scheneider, and R.S. Evet. 1997. Subsurface and surface microirrigation of corn southern high plains. Transactions of ASAE 40:635-641.

Humphreys, L., B. Fawcett, C. O'Neill, and W. Muirhead. 2005. Maize under sprinkler, drip and furrow irrigation. IREC Farmers' Newsletter 170:35-38.

Iptas, S., and A. Acar. 2006. Effects of hybrid and row spacing on maize forage yield and quality. Plant, Soil and Environment 52:515-522. 
Karasahin, M. 2013. Effects of different irrigation methods and plant density on silage yield and yield components of PR 31Y43 hybrid corn cultivar. Turkish Journal of Agriculture and Forestry. Available at http://journals.tubitak.gov.tr/havuz/tar-1302-36.pdf (accessed September 2013).

Karasahin, M., and B. Sade. 2011. Effects of different irrigation methods on grain yield and yield components of hybrid maize (Zea mays L. indentata S.) Journal of Agricultural Faculty of Uludag University 25:47-56.

Kheira, A.A.A. 2009. Comparison among different irrigation systems for deficit-irrigated corn in the Nile Valley. Agricultural Engineering International: the CIGR Ejournal 11:1-25.

Kırtok, Y. 1998. Mısır üretimi ve kullanımı. Kocaoluk Basımevi, Adana, Turkey.

Mstat-C. 1980. Mstat user's guides statistics $5^{\text {th }}$ ed. Michigan State University, East Lansing, Michigan, USA.

Ozturk, A., S. Bulut, and E. Boran. 2008. Effect of plant density on yield and some agronomic characteristics of silage maize. Atatürk University, Agricultural Faculty Journal 39:217-224.

Sade, B., and S. Soylu. 2008. Corn farming in Turkey and in the world. p. 101-108. National Grain Symposium, Konya, Turkey. 2-5 June.

Saruhan, V., and H.D. Sireli. 2005. An investigation on the effect of plant densities and nitrogen doses on ear, stem and leaf yields of maize (Zea mays L.) Journal of Agricultural Faculty of Harran University 9:45-53.
Schneider, A.D., T.A. Howell, and S.R. Evett. 2001. Comparison of SDI, LEPA and spray irrigation efficiency. ASAE Annual International Meeting, Sacramento, California. Paper nr 012019 29 July-1 August. American Society of Agricultural Engineers (ASAE), St. Joseph, Michigan, USA.

Stanton, D., A.W. Grombacher, R. Pinnisch, H. Mason, and D. Spaner. 2007. Hybrid and population density affect yield and quality of silage maize in central Alberta. Canadian Journal of Plant Science 87:867-871.

TIVT. 2010. Technical instructions on VCU tests. Republic of Turkey Ministry of Food, Agriculture and Livestock Variety Registration and Seed Certification Center, Ankara, Turkey.

Montemayor, J.A., O.A. Gómez, J. Olague, A. Zermeño, E. Ruiz, M. Fortis, et al. 2006. Effect of three driptape installation depths on water use efficiency and yield parameters in forage maize (Zea mays L.) cultivation. Técnica Pecuaria en México 44:359-364.

Tukel, T., and R. Hatipoglu. 1997. Meadow-pasture management. Agricultural Faculty Publishing, Adana, Turkey.

Turgut, I. 2002. Silage maize growing. p. 11-33. In Acıkgoz, E., I. Turgut, and I. Filya (eds.) Silage crops growing and silage making. Publishing of Hasad, Istanbul, Turkey.

Yilmaz, S., H. Gozubenli, O. Konuskan, and I. Atis. 2007. Genotype and plant density effects on corn (Zea mays L.) forage yield. Asian Journal of Plant Sciences 6:538-541. 